\title{
An Ultrasound Guided Percutaneous Breast Biopsy Simulator with Haptic Feedback
}

\author{
Haptik Geri Besleme Özellikli Ultrason Eşliğinde \\ Perkütan Meme Biyopsisi Simülatörü
}

\begin{abstract}
Objective: Breast cancer is the leading type of cancer in women worldwide and the number of cases is increasing in developing countries. Besides the other imaging diagnostic tools ultrasound guided breast biopsies are being performed for accurate diagnosis. This procedure requires hand-eye coordination skills with two dimensional ultrasound imaging and tracking biopsy needle.

Method: Ultrasound biopsy simulator incorporates a cohesive platform between virtual reality, physical objects, location sensors, haptic feedback data and scenarios. A game scoring system was also incorporated into software interface of the simulator. Silicone based breast and thorax model inserted in a torso were used as physical models. Ultrasound probe and biopsy needle were integrated with location sensors and haptic feedback device. A software interface with different training scenarios was developed. Results: Compared with the existing breast biopsy simulation modalities, the main advantages of this simulation system were that the breast lesions of different types could be generated at any quadrant of the breast tissue and the lack of needle tracks originating from the previous procedures.

Conclusion: A novel ultrasound based biopsy simulation system was created for breast lesions that may help to improve technical skills of trainees during the learning period of biopsy procedure. By adding other virtual anatomic and physical models, new modules for liver and renal biopsies can be added to the existing platform.
\end{abstract}

Keywords: ultrasonography, biopsy, simulation

\section{öz}

Amaç: Meme kanseri dünyada kadınlar arasında en önde gelen kanser tipi olup özellikle gelişmekte olan ülkelerde vaka sayılarında artış gözlenmektedir. Diğer görüntüleme tekniklerinin yanı sıra ultrason eşliğinde yapılan meme biyopsileri kesin tanı koyulabilmesi amacıyla uygulanmaktadır. Bu işlem iki boyutlu ultrason görüntüsü ile biyopsi iğnesinin takibinin el göz koordinasyonu ile yapılabilmesini gerektirir.

Yöntem: Ultrason biyopsi simülatörü sanal gerçekliği, fiziksel objeleri, konum sensörler verilerini, haptik geri besleme verilerini ve senaryoları birleştirmektedir. Simülatörün yazılım ara yüzüne puanlama sistemi de eklendi. Bir torso içine yerleştirilmiş silikon bazlı meme ve toraks modeli fiziksel model olarak kullanıldı. Ultrason probu ve biyopsi iğnesi konum sensörleri ve haptik geri besleme ünitesiyle entegre edildi. Birçok senaryoyu içeren kullanıcı ara yüzü oluşturuldu.

Bulgular: Mevcut meme biyopsisi simülasyon sistemleri ile karşılaştırıldığında bu sistemin avantajları memede değişik tipte lezyonların farklı kadranlarda oluşturulabilmesi ve daha önceki eğitimlerden herhangi bir iğne trasesinin görülmemesidir.

Sonuç: Meme biyopsi işlemi konusunda eğitim alanların teknik becerilerini arttırmak amaçlı yeni bir ultrason bazlı meme biyopsisi simülatörü geliştirilmiştir. Bu platforma sanal anatomik ve fiziksel modeller eklenerek ultrason destekli karaciğer ve böbrek biyopsisi modülleri de oluşturulabilir.
Alındığı tarih: 08.08.2019

Kabul tarihi: 19.08.2019

Yayın tarihi: 30.09 .2019

Mehmet Emin Aksoy Acıbadem Mehmet Ali Aydınlar Üniv. Biyomedikal Cihaz Teknolojisi Bölümü İstanbul - Türkiye

emin.aksoy@acibadem.edu.tr ORCiD: 0000-0003-3227-2660

Anahtar kelimeler: ultrasonografi, biyopsi, simülasyon 


\section{INTRODUCTION}

Breast cancer is the leading type of cancer in women worldwide and its incidence is increasing especially in developing countries. As an alternative to conventional surgical breast biopsy, percutaneous imagingguided needle breast biopsy is widely used for the diagnosis of breast lesions because it is a less invasive procedure ${ }^{(1-5)}$. Ultrasound guided breast biopsy has become the primary option for performing percutaneous needle biopsy procedures because ultrasound imaging technique has many advantages compared to other imaging modalities since it provides real time images and has no risk of radiation ${ }^{(2-7)}$. Besides the other imaging diagnostic tools ultrasound guided breast biopsies are being performed for accurate diagnosis of breast cancer. This procedure includes hand-eye coordination skills of the 2 dimensional ultrasound imaging and tracking of the 3 dimensional biopsy needle to target a mass in breast tissue.

Simulation based education is nowadays widely used for undergraduate and postgraduate healthcare trainings. In parallel to ultrasound simulators aiming to train the resident medical doctors for diagnostic ultrasonography, new simulators have been developed with the aim of training for ultrasound based percutaneous biopsies ${ }^{(8-12)}$. Ultrasound simulation systems reduce the stress of the trainee and the potential harm to the patient by providing an unpressurized learning environment and no risk for the patient ${ }^{(13)}$. Ultrasound based simulators provide a distinctive improvement in confidence level of trainees for varied ultrasound guided biopsy procedures such as renal biopsy ${ }^{(10)}$, liver biopsy ${ }^{(14,15)}$ and prostatic biopsy ${ }^{(9)}$.

There are several studies for simulating percutaneous ultrasound guided breast biopsy procedure to teach the procedure by using training models of silicone like materials, cadaveric tissues or animal tissues ${ }^{(8,11)}$. All these models have disadvantages like the risk of infection, storage problems, fixed loca- tions, same type of lesions or the existence of needle tracks originating from the previous training ${ }^{(11)}$. The disadvantages of the existing ultrasound guided breast biopsy simulation modalities are shown on Table 1.

Table 1. Disadvantages of the existing modalities for ultrasound guided breast biopsy training modalities.

\begin{tabular}{|c|c|c|}
\hline Simulation Modality & & advantages \\
\hline $\begin{array}{l}\text { Models created with } \\
\text { animal tissues }\end{array}$ & $\begin{array}{l}0 \\
0 \\
0\end{array}$ & $\begin{array}{l}\text { Risk of infection } \\
\text { Time required for preparation } \\
\text { Requires an ultrasound device }\end{array}$ \\
\hline $\begin{array}{l}\text { Models made of } \\
\text { silicone or similar } \\
\text { materials }\end{array}$ & $\begin{array}{l}0 \\
0 \\
0 \\
0 \\
0\end{array}$ & $\begin{array}{l}\text { Fixed position and same type of lesions } \\
\text { Needle tracks after each procedure } \\
\text { Requires an ultrasound device } \\
\text { No proper haptic feedback } \\
\text { Expensive }\end{array}$ \\
\hline Cadaver models & $\begin{array}{l}0 \\
0 \\
0 \\
0\end{array}$ & $\begin{array}{l}\text { No breast lesions } \\
\text { Risk of infection } \\
\text { Requires an ultrasound device } \\
\text { Availability problems }\end{array}$ \\
\hline
\end{tabular}

This study aimed to design an ultrasound guided breast biopsy simulator without the disadvantages mentioned above in order to teach ultrasound guided breast biopsy and to enhance operators' skills and to reduce training time. The new simulator should also have a dedicated Learning Management System (LMS) compliant with international SCORM/Tin Can (Experience API - xAPI) standards in order to store the score of each trainee ${ }^{(16,17)}$. The motivation behind using SCORM/Tin Can (Experience API - XAPI) standards was that these data could be exported to other databases much more easily ${ }^{(16,17)}$.

\section{METHODS and MATERIALS}

The main goal of the simulation platform was to create a realistic simulated real-time ultrasound image based on precise relative locations of the ultrasound probe, biopsy needle and the organ. To achieve this, location and orientation of each of these components had to be tracked in real time with sub-millimeter precision. This tracking is obtained by using a magnetic 6DOF (6 Degrees-Of-Freedom) Polhemus Patriot motion tracking system, consisting of a mag- 
netic source and two micro sensors. The tracker placement in the ultrasound probe mock-up can be seen on Figure 1.
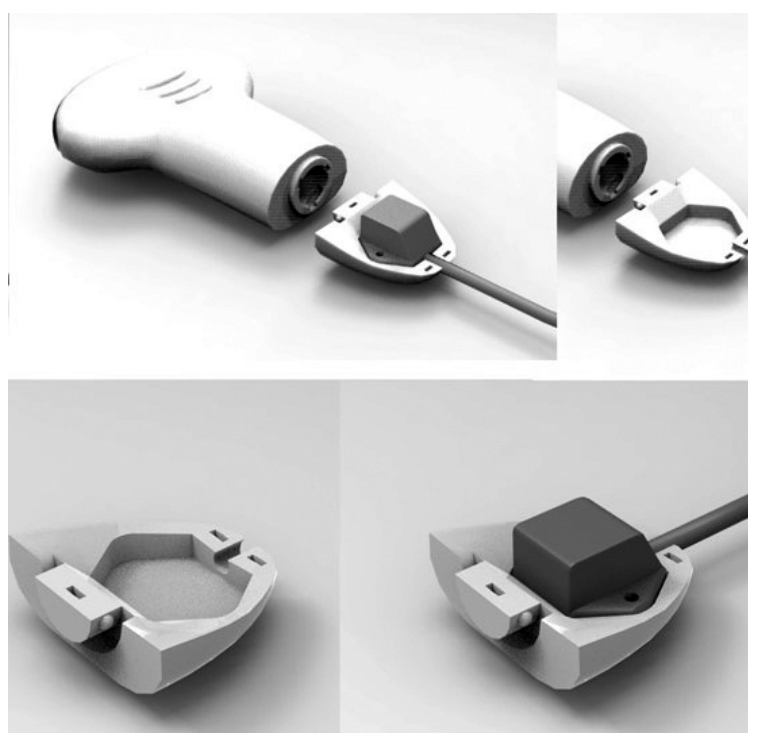

Figure 1. Tracking sensor embedded in the ultrasound probe mock-up.

With this system, the location and orientation of the probe and needle relative to the organ can be tracked in real time with $60 \mathrm{~Hz}$ sampling rate with 0,15 $\mathrm{mm}$ positional and 0,004 degrees orientational resolution. Based on this information, a mathematical model based on ultrasound source (probe location and orientation) and targets (needle and organ) were used to create a simulated ultrasound image. The breast and axillary tissues are modeled in 3D where different tissue types with different acoustic properties are identifiable. The simulated ultrasound images were compared with real ultrasound images to fine-tune the resulting images.

To simulate the haptic feedback for the biopsy needle a Geomagic Touch haptic system was used as seen on Figure 2.

In the final phases of the study, it has been decided to use a torso for breast palpation training purposes instead of using an in-house produced silicone model. Therefore, 3B Scientific Breast Examination

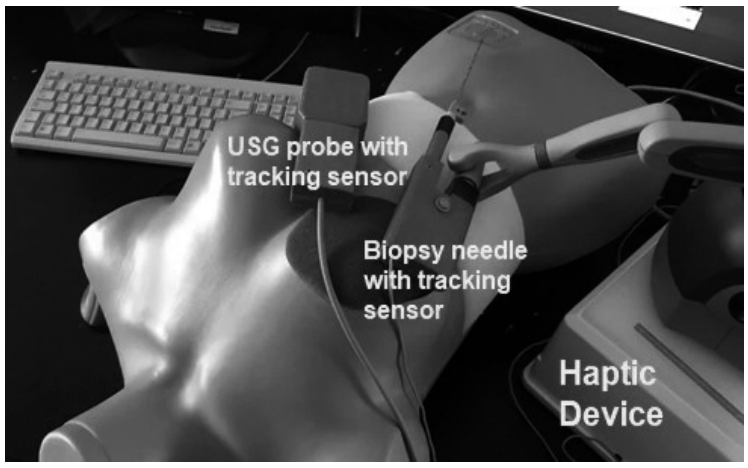

Figure 2. Ultrasound probe and biopsy needle with embedded trackers and the haptic device connected to the biopsy needle.

skills trainer torso was modeled and virtual lesions with different pathologies were integrated with this model. Another advantage of using this model was also the possibility of showing axillary pathologies. The latest version of the simulation platform can be seen on Figure 3. As there are benign or malign tumor like breast lesions, that can be detected in the initial ultrasound scanning phase, the trainee has decide on the indication of performing a biopsy or not.

\section{RESULTS}

After the harmonization of the 6 DOF tracking systems with the ultrasound probe mock-up and the biopsy needle, the first breast ultrasound images could be generated and a screen capture of these images and probe position be seen on Figure 4 .

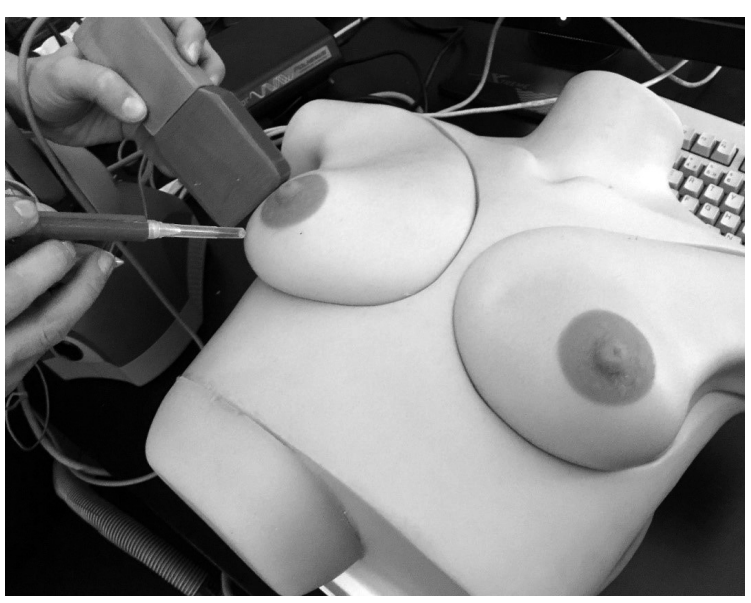

Figure 3. The final version of the simulation platform. 


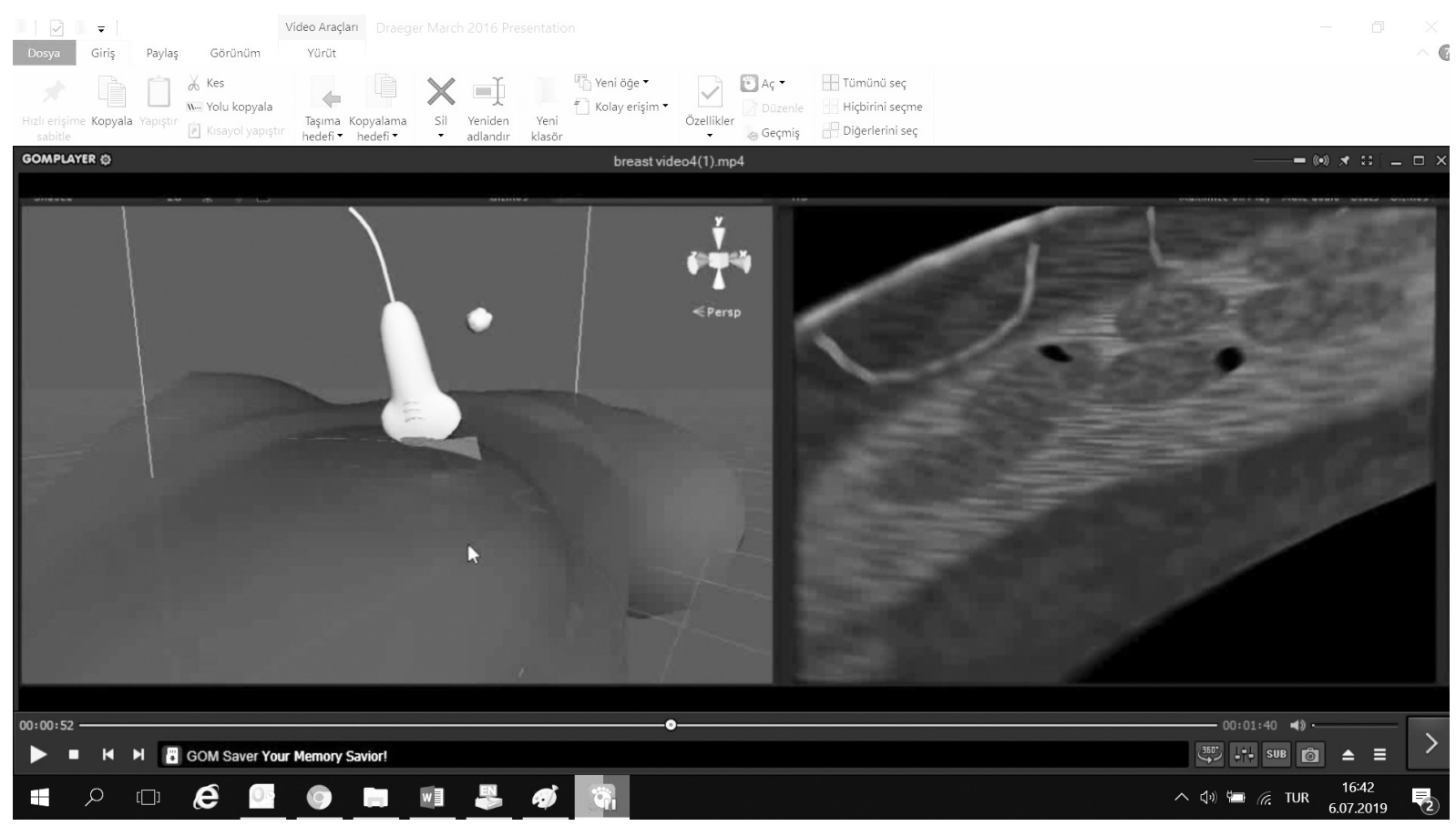

Figure 4. Breast ultrasound image created by the platform and the probe position.

The ultrasound biopsy simulator provides the following features:

- A detailed anatomy of breast and thorax.

o Different lesion types at different quadrants of the breast.

o The trainee has to decide for the indication of the biopsy procedure depending on the images of different lesions looking like benign or tumor like lesions.

- Location sensors for ultrasound probe and biopsy needle models.

o Haptic feedback.

- A user-friendly interface for learners.

o Learning Management System (LMS) that is compliant with international SCORM/Tin Can (Experience API-xAPI) standards.

In training mode, an additional graphical tool helps the trainee to target the needle to the lesion by calculating the actual location and direction of the needle with respect to the lesion in 3D. The system provides a signal to the trainee when the biopsy needle is in the correct position to take a biopsy sample.
Before starting the training, the trainee has to login to system with provided user credentials. In this phase, the LMS only records the actions of the trainees. Once the trainee has completed the training phase and is confident enough to proceed to the test mode, the LMS records the following performance measures:

- Is any blood vessel damaged? (if yes that causes a failure of the test)

- Has the lesion been penetrated by the biopsy needle?

- Is a biopsy sample taken when the needle was in correct position?

For each session, student login credentials, date and time of the test and scores for each of the performance items is reported by the application to the XAPI LMS.

\section{DISCUSSION}

This simulation platform for simulating ultrasound guided breast biopsy procedures provides many 
advantages compared with the existing simulation modalities. As all the breast lesions are created virtually by the system, there are no fixed lesions in the silicone material and there are no needle tracks originating from the previous trainings. There is no need for an actual ultrasound device for the trainings performed with this simulation platform, thus ultrasound systems can be used more for clinical activities. Training scores of trainees can be stored by the dedicated LMS on individual level. By this way past performances and the progress in the scores can easily be monitored. The simulation system can easily be transported to any place, because it consists of a compact torso, a notebook PC, ultrasound probe mock-up and biopsy needle. This simulation system requires no animal or cadaveric tissues for training and there is no risk of infection as this is the case for some training modalities for this purpose ${ }^{(11)}$.

Although applicability of developed simulator was experienced, widespread usage and integration of designed simulator into educational programs requires validity of the prototype simulator ${ }^{(18,19)}$. Therefore we will be focusing on validation studies of this system in measurement aspects like measuring effectiveness of simulator on the training resident medical doctors in our future studies.

\section{CONCLUSION}

A novel ultrasound simulation system was created for percutaneous breast biopsy trainings that may help to improve technical skills of trainees during the learning period of breast biopsy procedure. This simulator can serve as an additional training modality to teach ultrasound guided breast biopsy procedure to resident medical doctors before performing the procedure on real patients. Following validation process, this simulator can also be adapted to other minimally invasive procedure trainings such as ultrasound guided percutaneous liver biopsy, kidney biopsy or transrectal ultrasound guided prostatic biopsy procedures.
Acknowledgements: I would like to thank Assist. Prof. Dr. Dilek Kitapcioglu, Dr.Feray Güven and Dr.Erhan Sayalı for their great support during this study.

Ethics Committee Approval: The content of this study includes the design steps of ultrasound-guided breast biopsy simulator and its technical differences with similar training methods currently available on the market. Since this system has not been tested on any human or animal, no ethics committee report has been received.

Conflict of Interest: The author reports no conflict of interest.

Funding: This study has been supported financially with project code number 3160076 within the scope of TÜBITAK 1501-Industry Research Technology Development and Innovation Projects Support Program.

\section{REFERENCES}

1. White R, Halperin TJ, Olson JA, Jr. Soo MS, Bentley RC, Seigler HF. Impact of core-needle breast biopsy on the surgical management of mammographic abnormalities. Ann Surg. 2001;233(6):769-77. https://doi.org/10.1097/00000658-200106000-00006

2. Apesteguia L, Pina LJ. Ultrasound-guided core-needle biopsy of breast lesions. Insights Imaging. 2011;2(4): 493-500. https://doi.org/10.1007/s13244-011-0090-7

3. Liberman L. Percutaneous imaging-guided core breast biopsy: State of the art at the millennium. American Journal of Roentgenology. 2000;174(5):1191-9. https://doi.org/10.2214/ajr.174.5.1741191

4. Liberman L, Feng TL, Dershaw DD, Morris EA, Abramson AF. US-guided core breast biopsy: Use and cost-effectiveness. Radiology. 1998;8(3):717-23. https://doi.org/10.1148/radiology.208.3.9722851

5. Schueller GC, Schueller W, Helbich TH. Accuracy of ultrasound-guided, large-core needle breast biopsy. European Radiology. 2008;18(9):1761-73. https://doi.org/10.1007/s00330-008-0955-4

6. Schulz-Wendtland R, Kramer S, Lang N, Bautz W. Ultrasonic guided microbiopsy in mammary diagnosis: Indications, technique and results. Anticancer Research, 1998;18(3c):2145-6. Available from: https:// www.ncbi.nlm.nih.gov/pubmed/9703772.

7. Parker SH, Jobe WE, Dennis MA, et al. Us-Guided Automated Large-Core Breast Biopsy. Radiology. 1993; 187(2):507-11 
https://doi.org/10.1148/radiology.187.2.8475299

8. Blum T, Rieger A, Navab N, Friess H, Martignoni M. A Review of Computer-Based Simulators for Ultrasound Training. Simulation in Healthcare, 2013;8(2):98-108. https://doi.org/10.1097/SIH.0b013e31827ac273

9. Chalasani V, Cool DW, Sherebrin S, Fenster A, Chin J, Izawa JI. Development and validation of a virtual reality transrectal ultrasound guided prostatic biopsy simulator. Can Urol Assoc J. 2011;5(1):19-26. https://doi.org/10.5489/cuaj.09159

10. Dawoud D, Lyndon W, Mrug S, Bissler JJ, Mrug M. Impact of ultrasound-guided kidney biopsy simulation on trainee confidence and biopsy outcomes. Am J Nephrol. 2012;36(6):570-4. https://doi.org/10.1159/000345305

11. Farjad Sultan S, Shorten G, lohom G. Simulators for training in ultrasound guided procedures. Med Ultrason. 2013;15(2):125-31. Available from: https:// www.ncbi.nlm.nih.gov/pubmed/23702502. https://doi.org/10.11152/mu.2013.2066.152.sfs1gs2

12. Hugh JR, John TP, Leonard B. Simulation in Radiology. Oxford, UK: Oxford University Press. https://doi.org/10.1093/med/9780199764624.001.0001

13. Gibbs V. The role of ultrasound simulators in education: an investigation into sonography student experiences and clinical mentor perceptions. Ultrasound (Leeds, England), 2015;23(4):204-11. https://doi.org/10.1177/1742271X15604665

14. Villard PF, Vidal FP, Cenydd L, et al. Interventional radiology virtual simulator for liver biopsy. International
Journal of Computer Assisted Radiology and Surgery. 2014;9(2):255-67. https://doi.org/10.1007/s11548-013-0929-0

15. Johnson SJ, Hunt CM, Woolnough HM, et al. Virtual reality, ultrasound-guided liver biopsy simulator: development and performance discrimination. $\mathrm{Br} J$ Radiol. 2012;85(1013):555-61. https://doi.org/10.1259/bjr/47436030

16. Bakhouyi A, Dehbi R, Banane M, Talea MA. Semantic Web Solution for Enhancing The Interoperability of E-learning Systems by Using Next Generation of SCORM Specifications. International Journal of Emerging Technologies in Learning. 2019;14(11):174-85. https://doi.org/10.3991/ijet.v14i11.10342

17. Wu Q, Wang PW, Liu ER, et al. Design and Implementation of Learning Management Platform for Aviation Flight Training Based on SCORM/AICC Standard-A Case Study of K Airline Company Flight Training Learning Platform. Advanced Science Letters. 2018;24(7):5194-8. https://doi.org/10.1166/asl.2018.11700

18. Schout BMA, Hendrikx AJM, Scheele F, Bemelmans BLH, Scherpbier AJJ. A. Validation and implementation of surgical simulators: a critical review of present, past, and future. Surgical Endoscopy and Other Interventional Techniques, 2010;24(3):536-46. https://doi.org/10.1007/s00464-009-0634-9

19. McDougall EM. Validation of surgical simulators. Journal of Endourology. 2007;21(3):244-247 https://doi.org/10.1089/end.2007.9985 